\title{
Digitisation of Scenic and Historic Interest Areas in China
}

\author{
Chen Yang ${ }^{\mathrm{a}, *}$, Gillian Lawson ${ }^{\mathrm{b}}$, Jeannie Sim ${ }^{\mathrm{c}}$ \\ ${ }^{\text {a }}$ World Heritage Institute of Training and Research for the Asia and the Pacific Region under the auspices of UNESCO (WHITRAP) \\ - tjyangchen@126.com \\ ${ }^{\mathrm{b}}$ Dept. of Landscape Architecture, Queensland University of Technology, Brisbane, Australia - g.lawson@qut.edu.au \\ ${ }^{c}$ Dept. of Landscape Architecture, Queensland University of Technology, Brisbane, Australia - j.sim@qut.edu.au
}

\section{Topic E, E-2}

KEY WORDS: Digital Scenic Area project, Scenic Area, representation, Slender West Lake, China

\begin{abstract}
:
Digital documents have become the major information source for heritage conservation practice. More heritage managers today use electronic maps and digital information systems to facilitate management and conservation of cultural heritage. However, the social aspects of digital heritage have not been sufficiently recognised. The aim of this paper is to examine China's 'Digital Scenic Area' project, a national program started in 2004, to reveal the political and economic powers behind digital heritage practice. It was found that this project was only conducted within the most popular tourist destinations in China. Tourism information was the main object but information about landscape cultures were neglected in this project. This project also demonstrated that digital management was more like a political or economic symbol rather than a tool for heritage conservation. However, using digital technologies are still considered by the local government as a highly objective way of heritage management. Selected as a typical Scenic Area in China, Slender West Lake in Yangzhou was investigated to identify heritage stakeholder's attitudes toward digital management and the request from local management practice.
\end{abstract}

\section{INTRODUCTION}

\subsection{Background}

Over the past four decades significant progress has been made in developing and implementing digital tools that acquire, store, analyse, and share geographic information describing the characteristics of specified locations on the Earth's surface (Goodchild and F 2009). In the cultural heritage field, since United Nations Educational, Scientific and Cultural Organisation (UNECSO) first used a computer-assisted information management system in 1992 to help the Cambodian government to protect Angkor Wat, the rapid rise in digital technologies has revolutionised the representation of cultural heritage. Such innovative and research-focused uses of digital technologies have become critical issues in the global heritage conservation arena (Matero and Santana 2010).

The term 'digitisation' in this paper is defined as 'a process of producing electronic versions of documents and representations of heritage areas to facilitate management and conservation'. For example, management authorities of a heritage area produce digital representations of the physical components of a heritage area to assist their planning and management. Digital maps and virtual reality model are often used for this purpose. Additionally, authorities also produce digital copies of historic artefacts related to the heritage area, such as a digital copy of a historical painting, to facilitate their research and management. Within the context of heritage conservation, these processes could be deemed as 'digitisation'.

Digital documents have become the main means of communication and transmission of information of heritage places during the last four decades. UNESCO (2003) declared the Charter on Preservation of Digital Heritage to highlight that digital documents are a part of cultural heritage. Today, World Heritage nominations must be in electronic format to create a uniform heritage archive for periodic monitoring (UNESCO 2009). On the one hand, some international programs, such as the Memory of the World Programme, raise awareness and build capacity to develop digital preservation strategies that are globally applicable. On the other hand, the Vancouver Declaration (UNESCO 2012) urges UNESCO's Member States to develop their domestic theories and laws to ensure that digital heritage is well preserved.

This international progress has greatly impacted heritage conservation and management in China who is conducting both national and individual projects to catch up with this trend. For example, in 2004, the 'Digital Scenic and Historic Interest Area' project (DSA project) (国家级风景名胜区数字化建设) was a national project promoted by the China Construction Ministry (CCM) to digitalise the management systems of 24 Chinese Scenic and Historic Interest Areas (Scenic Areas). Under this program, CCM monitored more than 50 National Scenic Areas by remote sensing devices, and the 24 pilot Scenic Areas have already built their own digital management systems.

Another example is the 'Grottoes of Dunhuang' project (数字敦 煌), one of the earliest digital heritage projects in China. Today, Dunhuang project has become an iconic Chinese project and the 3D modelling and visualization technology has made substantial impacts on the international cultural heritage arena. Other international cooperation projects have influenced the Chinese digital heritage research and practice, such as the 'Scottish Ten' project used cutting edge technology to create accurate digital models of Scotland's five World Heritage Sites and five international heritage sites (Wilson et al. 2013) including the Eastern Qing Tombs (清东陵) in China.

* Corresponding author 
Despite increasing numbers of heritage sites being digitalised and more innovative technologies being imported from overseas, there are still many problems in terms of scale, cost and national standards, which result in low efficiency and resource waste in heritage management and conservation. Many researchers argue that these problems are caused by the lack of professionals and technicians in China and accordingly more research has been focusing on technological problems ( $\mathrm{Li}$ and Wei 2012; Liu 2008; Zhang 2004). However, rather than considering this movement a technological issue, this paper maintains that it was a politically and economically constructed practice. As a kind of representation, the social aspects of the Digital Scenic Area project needs to be deeply understood.

Landscape representation started to be concerned as cultural and social constructions in the late 1980s with the development of Critical Cartography (Crampton and Krygier 2005). Harley (1989) argued that the process of landscape representation was not a neutral, objective pursuit but rather was one laden with power relations. Landscape representation was considered as a process of revealing and creating knowledge which includes many subjective decisions about what to include, how the representation will look and what it is seeking to express.

Since the 1980s, research has been focused on how landscape representations are constituted in and through diverse, discursive and material processes, and focused on representation practices including their conceptualisation, production, and consumption. Corner $(1999,25)$ argued that cartographic theory needed to explore not only what maps represent and mean, but also what they do. Promoted by Crampton (2003), there was a move towards considering representation as constellation of ongoing process. Representation was conceptualised as a suite of cultural practices involving action and affects, a kind of approach reflects a philosophical shift towards performance and mobility and away from essence and material stability (Dodge, Kitchin, and Perkins 2009, 17).

Wood and Fels (2008) extend the notion of landscape representation as social construction to argue that representations can change the world by making propositions. Pickles (2004) pointed out that representation does not simply describe the world, it is part of the interplay between the world and us. Corner (1999) highlighted the role of representations in the globalisation process by saying that "visual representation has an unprecedented communicative significance in a politically, economically, technically and culturally globalizing world."

Today, the emerging digital technologies have greatly expanded the capacity of landscape representation, and within this process digital representations have been applied as a media to reinforce, influence or alter contemporary beliefs of landscapes. However, the social and cultural dimensions of digitisation have been omitted during the massive process of applying innovative technologies in China. Using digital tools has been mainly concerned as a 'modern' or scientific method.

Therefore, the aim of this paper was to explore the Digital Scenic Area (DSA) project in the context of China's political and economic goals. This aim will be achieved through answering two research questions: 1) what are the characteristics of DSA project in China? And 2) what is the social context of these characteristics?

This paper explored China's DSA project as an example of the digital heritage movement from a perspective of landscape representation. Firstly, this paper examined the sequence and character of the DSA project. Secondly, this paper explored the feature of the conceptualisation, production and consumption of the DSA project. Lastly, this paper revealed the underpinning political and economic powers of the DSA project. Based on an understanding of the DSA project, Slender West Lake was then investigated as an example of this movement to demonstrate the local stakeholder's attitudes toward digital management and reveal the local requirements.

\section{THE DIGITAL SCENIC AREA PROJECT (2004-2013) IN CHINA}

\subsection{Scenic and Historic Interest Areas in China}

Scenic and Historic Interest Area (Scenic Area) is a national system established by the Chinese Central Government in 1979. Scenic Area is a designated national park system, one that is different from the National Park systems in Western countries (Luo and Lawson 2011). China's Scenic Areas are characterised by outstanding natural and cultural qualities (Han 2007). Therefore the Scenic Areas in China are invaluable cultural heritage. Today, an entire system of 250 Scenic Areas has been nominated at the national level. These areas are directly managed by the local government under the supervision of the Ministry of Housing and Urban Plan Department (China's Construction Ministry before March 2008).

\subsection{The DSA Project}

In 2004, the China's Construction Ministry established the "Digital Scenic Area" project (DSA project) as a part of the national project - 'The digitisation of planning, design, construction and service of cites' (城市规划、建设、管理与服 务数字化工程), under the “Tenth Five-Year-Plan” (国家“十 一五' 计划) in China. China's Construction Ministry started initially with 18 pilot Scenic Areas, the number expanded to 24 in 2006. As a top-down program, China's Construction Ministry released the Recommendations of Building Digital Management Systems for National Scenic Areas (国家级风景名胜区数字化 景区建设指南) in 2005 to guide these pilot projects. Currently, most of these 24 pilot sites have already built digital management systems.

The information about the 24 pilot projects was accessed through public documents including the official local government website and social media. Six factors were designed to characterise the DSA project, which included site selection, tourism development, landscape types, digitisation themes, project objectives, and application problems. These factors were identified from the project documents through a content analysis method.

\subsection{Characteristics of the Pilot Projects}

The DSA project selected 24 pilot sites by using two criteria: (1) a pilot site should have a good infrastructure for digital management, such as a video monitor system and (2) the management authority should maintain a positive attitude towards digital management and be willing to invest in new projects. Consequently, the selected sites were some of the most successful Scenic Areas in China.

Most of these 24 pilot sites were the most popular tourist destinations in China. Among these 24 pilot sites, 17 were World Heritage properties and another site had an international 
heritage title - the Mount Yuntai in Henan Province is a Global Geopark (Appendix 1). The average visitor number for the 24 sites was about 4.5 million per year, with the West Lake in Hangzhou, the most popular site with more than 10 million visitors in 2009. Even the Tianshan Scenic Area in Xinjiang province, had 830,000 visitors in 2006.

In terms of heritage types, 20 of the 24 pilot sites were cultural landscapes with outstanding cultural values (Appendix 1). Few of them however built a comprehensive digital system to integrate cultural values. Among the 17 World Heritage sites, 13 of them were claimed as Cultural Heritage, Cultural Landscape or Mixed Heritage (Appendix 1). But even the other four 'Natural Heritage' sites still contained some significant cultural values. For example, Jiuzhaigou Scenic Area is a World Natural Heritage. Yet nine communities of the Tibetan people lived in this area for thousands of years, formed a unique cultural landscape (Wang 2011). The Stone Forest Scenic Area is another example. While today it is well known for the limestone formations, the Sani people lived in this region for more than 2,000 years (Zhao 2012). A world-famous long narrative poem, Ashima (阿诗玛), was created based on the true story of this ethnic group. Among the other 7 National Scenic Areas, there are only two sites featured by outstanding natural values - Jingyuetan Scenic Area and the Mount Yuntai. The other five areas are all cultural landscapes with rich historic or cultural meanings. However, the digital management systems established in the DSA project mainly focused on natural values. The cultural values of these heritage sites have not been fully represented.

According to the analysis of the 24 pilot projects, tourist service was the largest theme of these digitisation projects, including eight sub-categories (Figure 1). Heritage conservation was only a sub-category of the "landscape monitoring system". Within the 24 pilot sites, only 6 of them established cultural heritage management systems. The information of cultural values was neglected in other digital systems. Even among these 6 sites, however, what the systems can do is not much than monitoring some important heritage buildings.

\section{TOURIST SERVICE}

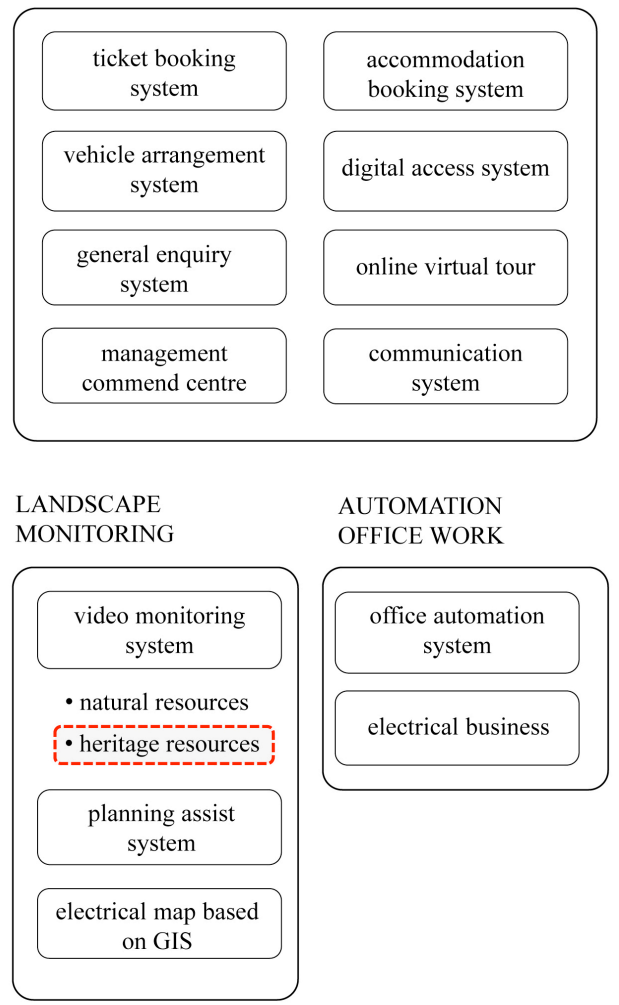

Figure 1. Categorisation of 24 project reports into themes and 13 subthemes of the pilot digital management projects

Other than focusing on heritage conservation, these pilot projects demonstrated quite diverse objectives. The local authorities gave many interpretations to these digitisation projects by saying that: "With a digitisation project, our Scenic Area could be an international tourist destination. Digitisation is the significant step to construct an international resort". Additionally, scientisation or modernisation was another title for these digitisation projects. Many authorities thought that having a digital management system meant the site was scientifically managed and became a modern resort, while they did not know how to use the system.

\subsection{Problems of the DSA Project}

Since the DSA project was launched in 2004, researchers and managers have identified some problems. Firstly, this project lacks of a unified understanding of digitisation. Some local authorities have not realised the importance of digitisation, while others put too much emphasis on technologies. Secondly, many projects were in broad-scale but not for specific requirements. Many new systems built by the "top-down" process cannot be integrated in domestic management contexts (Zhu and $\mathrm{He}$ 2013). At the local level, the ability of manipulating those systems is very limited and cannot be built by a short time.

The third problem is the weak information infrastructures. In China, the state financial input at present is less, and Scenic Area management funds, including those for DSA projects, mainly come from ticket sales. Fourthly, it was found that natural and ecological aspects of landscapes have been the main aspects in the digital system, in which cultural values were 
neglected. Lastly, the project lacks of unified platforms, standards and regulations at the national level, which result in low efficiency and resource waste.

\section{THE CASE OF SLENDER WEST LAKE SCENIC AREA}

Slender West Lake Scenic Area (Slender West Lake) in Yangzhou is a National-level Scenic and Historic Interest Area. It is a typical Chinese cultural landscape with 2,500 years history. Currently, Slender West Lake is part of two Tentative World Heritage sites in China: The Chinese Grand Canal (UNESCO 2008) and Slender West Lake and the Historic Urban Area in Yangzhou (UNESCO 2008).

The most representative digitisation project for Slender West Lake was the "Grand Canal (Yangzhou Section) Monitoring and Alert Platform” (大运河扬州段遗产监测预警平台) triggered by these World Heritage application projects. The local government of Yangzhou established this platform as a part of the World Heritage application program in 2012. Slender West Lake is one heritage site in the system. World Heritage application was the main aim of building this platform. In a project report, a project manager said that: "this platform will play an important role in the evaluation of international expert committee" (Zhang 2013). From a rhetoric perspective, the audience of this representation might be the evaluator from World Heritage committee, rather than the local managers.

Additionally, this system has different management objects. The Grand Canal was the main conservation object of this system, which is a linear cultural heritage including many heritage spots in 35 cities throughout China. Slender West Lake is only one spot of them. Therefore, the system was in a very broad and abstract scale, and many elements of Slender West Lake cannot be integrated into the system. Some significant management requirements were not addressed in the digital system of Slender West Lake.

Slender West Lake was explored as a case study to explore the heritage stakeholder's attitudes and expectations of the digital management system. Semi-structured interviews with Slender West Lake's stakeholders were conducted in October 2013. The interviewees included park managers, planners, heritage experts, tour organisers, historians and local visitors. One of the four open-ended questions related to this paper was that "if we want to build a digital management system for Slender West Lake, what information you consider should be integrated into the system?"

Generally, most stakeholders agreed that digitisation is going to be a trend of landscape management in the near future. But they provided different explanations: a landscape planner in the management group argued that it is necessary to set up a database because it is a compulsory work for World Heritage application. A park manager pointed out that a digital monitoring system can greatly improve the efficiency of management. Today it is impossible to manage a scenic area like Slender West Lake without new technologies. A commercial tour organiser in Slender West Lake argued that the management of Slender West Lake has to be digitalised because "many Scenic Areas have already done that, and we do not want to be left behind and we need to be more competitive in the tourism market".
Additionally, stakeholders have quite different expectations of the digital management. Staff management was one of the issues to be addressed by digital information systems. A park manager said that:

\begin{abstract}
"Through a digital system (of Slender West Lake), I want to access the updated information about the sanity of each spot in the park; also I want to check the situation of the staffs working in the park. I want to know whether they are doing a good job."
\end{abstract}

Additionally, a local visitor expressed different expectations by putting more concerns on visitors:

"I want to learn the information about the boat service, transportation and toilet in the park; and I want to know if I only got two hours to visit Slender West Lake, what I should see. What about only one hour?"

In contrast, demonstrating history seemed to be a more urgent problem than staff and tourism for some stakeholders. A tour guide who worked in Slender West Lake for more than 20 years said that:

"History is quite important compared to the other information, since Slender West Lake is a historic landscape. It is very difficult to understand its value and enjoy the great beauty of Slender West Lake if people do not know the history. So it is significant to investigate the history of Slender West Lake in detail and display it in an effective way."

Another park planner expressed the same expectation but he is more concerned about conservation methods:

\begin{abstract}
"Most of the Chinese historic buildings are made of timber, so restoration has been a regular and significant work for managers. But currently, how to maintain and restore them is remembered in the manager's heads, which is very unreliable. Therefore, as part of the heritage management instructions and policies, what has been done and what need to do have to be recorded in digital systems. It can be really dangerous if we lose that information."
\end{abstract}

The case of Slender West Lake shows some characteristics of the digitisation movement in China. The digitisation practice in Slender West Lake demonstrated a strong impact from World Heritage application. Some problems in the movement, such as unsuitable scales of representation in digital management systems, and neglected information of cultural values, were all reflected by the case of Slender West Lake. Additionally, the information of history and conservation methods is critical factors in the expected digital system of Slender West Lake.

\section{DISCUSSION - A SOCIALLY AND CULTURALLY CONSTRUCTED DIGITISATION MOVEMENT}

While most management authorities in China consider digitisation to be a scientific method of heritage conservation, data from the pilot projects demonstrated that the DSA project was very much a value-laden process including many subjective selections of landscape sites and components. Though the Chinese government responded to international digital heritage conservation movement, it was still confined by the Chinese political and economic contexts. 
The Chinese Central Government commissioned the Digital Scenic Area project. China welcomes globalization as a way to enrich national competitiveness and has endeavoured to catch up with international trends. Digital heritage conservation is one of those trends. Digitisation has become a substantial industry in many aspects of Chinese administrate and it was deemed to be an approach to enhance national competitiveness. As a result, the 'Digital Scenic Area' project was part of "the Tenth FiveYear-Plan" and partly became a political assignment for local governments.

Developing a tourism industry from heritage conservation was another national strategy of the Chinese Central Government, since its contribution to China's GDP cannot be achieved by other industries. According to the annual report from the World Travel and Tourism Council (2013), the direct contribution of travel and tourism to GDP in China was CNY 1, 361, 9 bn ( $2.6 \%$ of total GDP) in 2012 . The total contribution of travel and tourism to employment was $8.3 \%$ of the total employment $(63,779,000$ jobs). World Heritage sites and the National Scenic Areas are the major destinations for domestic and international tourists. Improving the management and service facilities of these destinations was therefore a goal of Digital Scenic Area movement.

Impacted by these political and economic influences, the selection of pilot sites was almost a value-laden process in which only some economically successfully Scenic Areas were included in the Digital Scenic Area project. The 'undeveloped' scenic areas were not selected for this program even though they also contain unique heritage sites and conservation significance. These areas were largely missing in this national strategy, and the digitisation process was therefore a reallocation of resources and power within the Chinese scenic area system.

For the 24 pilot sites, the DSA project was a government-led top-down process with some sites protected and some neglected. The central government promoted this program without a comprehensive survey of the diversity of cultural landscapes. The Recommendations of Building Digital Management Systems for National Scenic Areas (国家级风景 名胜区数字化景区建设指南) was a 'one-size-fit-all' guide to standardising multiple projects. The diversity of Chinese heritage landscapes was not reflected in this program. It was noticed that only two of the 24 pilot projects included comprehensive research into heritage issues, and none of them involved public participation in building digital program.

These digital management systems were created by the local government but in almost a subjective way. In applying World Heritage listing some local governments wiped away the preexisting local settlement from digital maps and replaced them with green polygons representing intact natural spaces, because this tends to take a better fit with the World Heritage framework of the United Nation. It was shown in Slender West Lake that the digital management system was fabricated a rhetorical component of World Heritage application rather than a useful management tool.

Economic factor was another underpinning reason for these subjective representations, because the title of World Heritage can attract a large number of tourists. Local governments only have limited access to management funds from the Chinese Central Government, which means they have to generate their own income to support management and conservation in every fiscal year (Fei 2003). Taking Slender West Lake Scenic Area as an example, the funds from the Central/Local Government has decreased from CNY 51,230,000 to 640,000 between 2002 and 2010, in contrast self funding has increased from CNY $30,520,000$ to $72,670,000$. This means that less than $1 \%$ of the funds now come from the Central Government (in 2010). As a result, tourist services were the largest category if of incoming generating activities in the digitisation of heritage sites.

But one of the most urgent problems shown by both the 24 pilot sites and Slender West Lake was that much valuable information about cultural traditions, symbolic meanings, oral histories, cannot be integrated into the current management system. The management system for cultural landscape heritage should be more comprehensive than the current one. Containing a large amount of intangible cultural heritage, such as legends, oral traditions, symbolic associations, is a significant feature of China's cultural landscapes. The information of these intangible cultural heritages is necessary factors for site management and decision-making. Mountain Lushan Scenic Area is a good example which has more than 3,000 poems created in its history. These poems are a significant part of Lushan culture demonstrating the historical meaning of the landscape. However, there was no digital database for these poems and even other intangible cultural heritage evidence in the digital archive of Lushan.

The separated administrative system in China might be a significant reason for the cultural-less digital scenic area project. In China, the Ministry of Construction and Urban Planning is responsible for scenic areas, while the State Administration of Cultural Heritage is in charge of cultural heritage affairs. This is partly why cultural values cannot be integrated into the scenic area system that is mainly for natural resources, while most scenic areas in China contain a large number of cultural heritages.

Tourists and the World Heritage evaluation committee were the two important consumers of digital management systems. The most developed topic was how to promote a Scenic Area and attract more tourists. Some technologies, such as virtual reality and 3D panorama images, were very common in those projects because they can greatly enhance visitor experience. Digitisation projects were an investment in tourism rather than heritage conservation. On the other hand, World Heritage was another drive for conducting digital projects. China today is the second largest country regarding World Heritage with 47 World Heritage listed properties. There are 48 heritage sites on the Tentative World Heritage List (2014), including more than 100 "bounded heritage sites" related to them. Both the central and local governments have devoted considerable energy and resources to World Heritage application.

\section{CONCLUSION}

Rather than a technological revolution, the DSA Project was a socially constructed practice. It included a reshuffling process of resources where economic and political influences played a significant role in this movement and cultural heritage values were neglected. Digital technologies were applied as a media to enforce the situation constructed by the contemporary political and economic context in China.

However, many local governments, especially the management authorities, are still considered this movement as an objective and scientific way of landscape conservation. The DSA Project was covered by the 'scientific' or 'modern' appearance. Some titles, such as 'globalisation', 'modernisation', 
'competitiveness', and 'successful' were used as symbols to constructed these digitisation projects. Yet the mechanism beneath the representation has not been changed. From this perspective, this movement is hardly an improvement of heritage conservation in China. It is therefore necessary to build a critical perspective for application of digital technologies.

\section{ACKNOWLEDGEMENTS}

The authors thank the experts and directors in the Office of World Heritage Application of Slender West Lake and Historic Urban Area of Yangzhou for their support in the data collection process.

\section{REFERENCES}

Corner, James. 1999. The Agency of Mapping: Speculation, Critique and Invention. In Mappings, edited by D. Cosgrove. London: Reaktion Books.

Crampton, J. 2003. The Political Mapping of Cyberspace. Edinburgh: Edinburgh University Press.

Crampton, J., and J. Krygier. 2005. An Introduction to Critical Cartography. ACME: An International E-Journal for Critical Geographies 4(1):34-56.

Dodge, Martin, Rob Kitchin, and Chris Perkins. 2009. Rethinking Maps: New Frontiers in Cartographic Theory, Routledge Studies in Human Geography. Abingdon: Routledge.

Duncan, James, and David Ley. 1993. Introduction: Representing the Place of Culture. In Placel Culture/ Representation, edited by J. Duncan and D. Ley. London: Routledge.

Fei, B. C. 2003. A Comparative Study on Management Machanism between National Park System in the United States and major Scenic Resorts in China. Geography and GeoInformation Science 19 (6):89-92.

Goodchild, and Michael F. 2009. Geographic information systems and science: today and tomorrow. Procedia Earth and Planetary Science 1 (1):1037-1043.

Han, Feng. 2007. Cross-Cultural Confusion: Application of World Heritage Concepts in Scenic and Historic Interest Areas in China. In The Great New Wilderness Debate, edited by J. B. Callicott and M. Nelson: University of Georgia Press.

Harley, J.B. 1989. Deconstructing the Map. Cartographica 26(2):1-20.

Head, C. G. 1984. The Map as Natural Language: A Paradigm for Understanding. Cartographica 31(1):1-32.

Latour, B. 1987. Science in Action. Cambridge, MA: Harvard University Press.

Li, Jun, and Haitao Wei. 2012. The Applications of Satellite Navigation Technology in Complex Scenic Environment. Paper read at The 3rd China Satellite Navigation Conference (CSNC 2012), May 15-19, at Guangzhou, China.
Liu, Lin. 2008. Geoinformatics 2008 and Joint Conference on GIS and Built Environment. The built environment and its dynamics: 28-29 June 2008, Guangzhou, China. Bellingham, Wash.: SPIE.

Luo, Tianqing, and Gillian Lawson. 2011. An Investigation of Unique Challenges in National Historic Relics and Scenic Sites in Chinese Research Literature 198202008 using Co-word Analysis. Journal of Tourism and Leisure Studies 17(2):293314.

Matero, Frank, and Mario Santana. 2011. Int'l Symposium on Heritage Recording \& Information Management in the Digital Age (SMARTDoc Heritage). UNESCO 2010 [cited 06-10 2011]. Available from http://whc.unesco.org/en/events/637.

Pickles, John. 2004. A History of Spaces: Cartographic Reason, Mapping and the Geo-Coded World. London: Routledge.

Schlichtmann, Hansgeorg. 1979. Codes in Map Communication. The Canadian Cartographer 16(1):81-97.

UNESCO. 2003. Charter on the Preservation of Digital Heritage, Records of the General Conference. Paris: UNESCO.

2008. The Grand Canal. In World Heritage Tentative List: UNESCO World Heritage Centre.

2008. Slender West Lake and Historic Urban Area in Yangzhou. In World Heritage Tentative List: UNESCO World Heritage Centre.

2009. World Heritage Cultural Landscapes: A Handbook for Conservation and Management. Edited by $\mathrm{N}$. Mitchell, M. Rossler and P.-M. Tricaud, World Heritage Papers. Paris, France: World Heritage Centre UNESCO.

2012. UNESCO/UBC Vancouver Declaration. Paper read at The Memory of the World in the Digital Age: Digitization and Preservation, at Vancouver, British Columbia, Canada.

Wang, Liangyan. 2011. Research on Developing Cultural and Tourism Resources of Tibetan Ethnic Group in Jiuzhaigou Valley, Tourism Management, Southwestern University of Finance and Economic, Chengdu.

Wilson, L., A. Rawlinson, D. S. Mitchell, H. C. McGregor, and R. Parsons. 2013. The Scottish Ten Project: Collaborative Heritage Documentation. In International Archives of the Photogrammetry, Remote Sensing and Spatial Information Science, 2013 XXIV International CIPA Symposium. Strasbourg, France.

Wood, D., and J. Fels. 2008. The Natures of Maps: Cartographic Constructions of the Natural World. Chicago: IL: University of Chicago Press.

World Travel \& Tourism Council, WTTC. 2013. Travel \& Tourism Economic Impact 2013: China. London: World Travel \& Tourism Council.

Zhang, Chuanrong. 2004. GIS, Remote Sensing and Spatial Modeling for Conservation of Stone Forest Landscape in Lunan, China, Geography, The University of WisconsinMilwaukee. 
Zhang, Yun. 2014. Project Report of the Digital Management Platform of the Grand Canal (Yangzhou Section) 2013 [cited 01.20 2014].

Zhao, Jujian. 2012. Research on Building Database of the Oral History Archive of Yi People in Stone Forest of Yunnan, Archival Science, Yunnan University, Kunming.

Zhu, Hongming, and Yue He. 2013. Analysis on Tourist Characteristics based on Rough Sets Theory and Apriori Algorithm. In Information Science and Management Engineering (Set), edited by P. Ren and Z. Du. Southampton, UK: WIT Press.

\section{APPENDIX}

Appendix 1. Categories of the pilot sites of the DSA Project

\begin{tabular}{|c|c|c|}
\hline Pilot sites & Category & World Heritage \\
\hline $\begin{array}{l}\text { The Great Wall - the } \\
\text { Badaling Section }\end{array}$ & Cultural Heritage & $\begin{array}{l}\text { Cultural } \\
\text { Heritage }\end{array}$ \\
\hline $\begin{array}{l}\text { Jingyuetan National } \\
\text { Park }\end{array}$ & $\begin{array}{c}\text { National Forest } \\
\text { Park } \\
\end{array}$ & \\
\hline $\begin{array}{l}\text { Mount Yuntai in } \\
\text { Jiangsu Province }\end{array}$ & Cultural Landscape & \\
\hline $\begin{array}{l}\text { West Lake in } \\
\text { Hangzhou }\end{array}$ & Cultural Landscape & $\begin{array}{c}\text { Cultural } \\
\text { Landscape }\end{array}$ \\
\hline Mount Putuo & $\begin{array}{l}\text { Religious } \\
\text { Landscape }\end{array}$ & \\
\hline Mount Jiuhua & Cultural Landscape & Mixed Heritage \\
\hline Mount Wuyi & Cultural landscape & Mixed Heritage \\
\hline Mount Lushan & Cultural landscape & $\begin{array}{c}\text { Cultural } \\
\text { landscape }\end{array}$ \\
\hline Mount Taishan & Cultural Landscape & Mixed Heritage \\
\hline $\begin{array}{l}\text { Mount Yuntai in } \\
\text { Henan Province }\end{array}$ & Geological Park & \\
\hline $\begin{array}{l}\text { Ancient Building } \\
\text { Complex in the } \\
\text { Wudang Mountains }\end{array}$ & Cultural Landscape & $\begin{array}{l}\text { Cultural } \\
\text { Heritage }\end{array}$ \\
\hline $\begin{array}{l}\text { Mount Heng, Nan } \\
\text { Yue }\end{array}$ & Cultural Landscape & \\
\hline $\begin{array}{l}\text { Wulingyuan Scenic } \\
\text { Area }\end{array}$ & Natural Landscape & $\begin{array}{c}\text { Natural } \\
\text { Heritage }\end{array}$ \\
\hline Mount Baiyun & Cultural Landscape & \\
\hline Mount Qingcheng & $\begin{array}{c}\text { Religious } \\
\text { Landscape }\end{array}$ & $\begin{array}{l}\text { Cultural } \\
\text { Heritage }\end{array}$ \\
\hline $\begin{array}{l}\text { Mount Emei Scenic } \\
\text { Area }\end{array}$ & $\begin{array}{c}\text { Religious } \\
\text { Landscape }\end{array}$ & Mixed Heritage \\
\hline Stone Forest & Ethnic Landscape & $\begin{array}{c}\text { Natural } \\
\text { Heritage }\end{array}$ \\
\hline Xinjiang Tianshan & Natural Landscape & $\begin{array}{c}\text { Natural } \\
\text { Heritage }\end{array}$ \\
\hline Mount Wutai & Cultural Landscape & $\begin{array}{l}\text { Cultural } \\
\text { Heritage }\end{array}$ \\
\hline $\begin{array}{l}\text { The Dujiangyan } \\
\text { Irrigation System }\end{array}$ & National Relics & $\begin{array}{l}\text { Cultural } \\
\text { Heritage }\end{array}$ \\
\hline $\begin{array}{l}\text { Jiuzhaigou Valley } \\
\text { Scenic and Historic } \\
\text { Interest Area }\end{array}$ & $\begin{array}{c}\text { Ethnic } \\
\text { Landscape/village }\end{array}$ & $\begin{array}{l}\text { Natural } \\
\text { Heritage }\end{array}$ \\
\hline Longmen Grottoes & Cultural Heritage & $\begin{array}{l}\text { Cultural } \\
\text { Heritage } \\
\end{array}$ \\
\hline Ming Dynasty Tombs & Cultural Heritage & $\begin{array}{l}\text { Cultural } \\
\text { Heritage }\end{array}$ \\
\hline $\begin{array}{l}\text { Sun Yat-sen } \\
\text { Mausoleum }\end{array}$ & $\begin{array}{l}\text { National AAAAA } \\
\text { Rank Tourist Area }\end{array}$ & \\
\hline
\end{tabular}

